\title{
Phosphorus removal in denitrifying woodchip bioreactors varies by wood type and water chemistry
}

\author{
Ana Paula Sanchez Bustamante-Bailon ${ }^{1} \cdot$ Andrew Margenot $^{1} \cdot$ Richard A. C. Cooke $^{2} \cdot$ Laura E. Christianson $^{1}$ (D)
}

Received: 21 January 2021 / Accepted: 2 August 2021 / Published online: 30 August 2021

(C) The Author(s) 2021

\begin{abstract}
Denitrifying woodchip bioreactors are a practical nitrogen $(\mathrm{N})$ mitigation technology but evaluating the potential for bioreactor phosphorus $(\mathrm{P})$ removal is highly relevant given that (1) agricultural runoff often contains $\mathrm{N}$ and $\mathrm{P},(2)$ very low $\mathrm{P}$ concentrations cause eutrophication, and (3) there are few options for removing dissolved $\mathrm{P}$ once it is in runoff. A series of batch tests evaluated $\mathrm{P}$ removal by woodchips that naturally contained a range of metals known to sorb $\mathrm{P}$ and then three design and environmental factors (water matrix, particle size, initial dissolved reactive phosphorus (DRP) concentration). Woodchips with the highest aluminum and iron content provided the most dissolved P removal (13 $\pm 2.5 \mathrm{mg}$ DRP removed $/ \mathrm{kg}$ woodchip). However, poplar woodchips, which had low metals content, provided the second highest removal $(12 \pm 0.4 \mathrm{mg} / \mathrm{kg})$ when they were tested with Pdosed river water which had a relatively complex water matrix. Chemical P sorption due to woodchip elements may be possible, but it is likely one of a variety of P removal mechanisms in real-world bioreactor settings. Scaling the results indicated bioreactors could remove 0.40 to $13 \mathrm{~g} \mathrm{DRP} / \mathrm{ha}$. Woodchip bioreactor dissolved P removal will likely be small in magnitude, but any such contribution is an added-value benefit of this denitrifying technology.
\end{abstract}

Keywords Batch test $\cdot$ Dissolved phosphorus $\cdot$ Oak $\cdot$ Poplar $\cdot$ Precipitation $\cdot$ Sorption

\section{Introduction}

Denitrifying woodchip bioreactors, woodchip-filled trenches where maintenance of anoxic conditions enhance denitrification, are a simple on-farm technology promoted for nitratenitrogen $\left(\mathrm{NO}_{3}-\mathrm{N}\right)$ treatment in agricultural drainage waters and effluents worldwide (Schipper et al. 2010). However, many areas impacted by non-point source $\mathrm{N}$ pollution also suffer from phosphorus (P)-related water quality impairment. Even though woodchip bioreactors leach nutrients, including P, upon start-up (Bell et al. 2015; Cameron and Schipper 2010; Healy et al. 2012), there have also been reports of $P$

Responsible Editor: Ta Yeong Wu

Laura E. Christianson

LEChris@illinois.edu

1 Department of Crop Sciences, University of Illinois at Urbana-Champaign, AW-101 Turner Hall, 1103 S. Goodwin Ave, Urbana, IL 61801, USA

2 Department of Agricultural and Biological Engineering, University of Illinois at Urbana-Champaign, 1304 W. Pennsylvania Ave, Urbana, IL 61801, USA removal by bioreactors although the mechanisms and fate of the $P$ are unclear (Husk et al. 2018). Woodchips can obviously act as a physical filter to trap sediment and particulate $\mathrm{P}$ (Choudhury et al. 2016; Sharrer et al. 2016), but beyond this, woodchip bioreactors have provided dissolved reactive $\mathrm{P}$ (DRP) removal ranging from 0.01 to $0.88 \mathrm{~g} \mathrm{DRP} / \mathrm{m}^{3}$-day (Dougherty 2018; Hua et al. 2016; Sharrer et al. 2016; von Ahnen et al. 2018) with Weigelhofer and Hein (2015) reporting removal as high as $166 \mathrm{~g}$ phosphate- $\mathrm{P} / \mathrm{m}^{3}$-day for straw-filled bioreactors. Dissolved P load and concentration reductions by woodchips across bioreactor literature have been as high as $>50 \%$ (Dougherty 2018; Hua et al. 2016; Husk et al. 2018), though most reported reductions are more moderate $(\approx 10 \%$; Goodwin et al. 2015; Warneke et al. 2011; Zoski et al. 2013). While DRP removal has been observed across a variety of studies, $\mathrm{P}$ removal in woodchip bioreactors has not been systematically tested.

Because even low concentrations of highly bioavailable DRP can trigger eutrophication in freshwater, it is important to better understand DRP interactions within denitrifying woodchip bioreactors. Any P removal provided by this denitrifying technology is a "free" added value. Four metal elements present in wood, calcium $(\mathrm{Ca})$, magnesium $(\mathrm{Mg})$, 
aluminum ( $\mathrm{Al})$, and/or iron $(\mathrm{Fe})$, capture $\mathrm{P}$ through precipitation and/or ligand exchange, depending on speciation (Penn et al. 2014; Penn et al. 2007). These four metals would each be present in bioreactor woodchip media, though in varying concentrations depending on tree species and environmental growth conditions (Koch 1985; Pettersen 1984). The primary objective of this study was to evaluate P sorption as a potential fate of DRP in woodchip bioreactors using small-scale batch testing with wood species containing a range of metal element compositions. It was hypothesized that woodchips containing relatively greater contents of $\mathrm{Al}, \mathrm{Fe}, \mathrm{Ca}$, and/or $\mathrm{Mg}$ would provide greater DRP removal than woodchips containing lower concentrations of those elements.

Secondary objectives included systematically testing three additional factors (water matrix, particle size, and initial DRP concentration) to more deeply evaluate $\mathrm{P}$ dynamics associated with woodchips in denitrifying bioreactors. A more complex water matrix was tested by evaluating P-dosed river water (as a proxy for agricultural runoff and drainage) compared to Pdosed deionized (DI) water. It was hypothesized that if the batch tests were performed with river water, then greater DRP concentration reductions would be observed due to an addition of microbes, micronutrients, and salinity in the river water. Next, two woodchip particle size ranges (3.2-6.3 vs. $6.3-13 \mathrm{~mm}$ ) were evaluated to test the hypothesis that greater DRP concentration reductions would be observed for smaller particle sizes due to the greater associated surface area. Lastly, it was hypothesized that a low initial concentration of $0.10 \mathrm{mg}$ $\mathrm{DRP} / \mathrm{L}$ compared to $1.0 \mathrm{mg} \mathrm{DRP} / \mathrm{L}$ would result in a greater concentration reduction but lower overall mass removal. This followed work by Hua et al. (2016) who reported phosphate removal rates by cottonwood (Populus sp.) woodchips of 0.25 and $0.88 \mathrm{~g} \mathrm{P} / \mathrm{m}^{3}$-day at respective inflow concentrations of 1.0 and $10 \mathrm{mg} \mathrm{P} / \mathrm{L}$ in column tests.

\section{Materials and methods}

\section{Woodchip characterization and preparation}

Seven wood types were selected based on general availability in the US Midwest region and a literature review of typical expected elemental contents (Fig. S1; Table S1). Cypress (Taxodium distichum) and white oak (Quercus alba) were obtained locally as live and deadfall branches (Monticello, IL, USA); hickory (Carya spp.) and poplar (Populus spp.) were obtained as untreated lumber from a home improvement store; and cedar (Cedrus spp.) and maple (Acer spp.) woodchips were obtained from a Midwestern supplier (Xylem Ltd, Cordova, IL, USA). Woodchips were also collected from a leftover pile at a full-size denitrifying bioreactor constructed in IL, USA, in October 2018 ("field bioreactor" chips) to provide a realistic comparison with woods of unknown origin. These woodchips were described by the contractor as an approximately 70/30 ratio of local hardwood/ softwood (Forrest, IL, USA) that were originally double ground on a commercial-scale grinder.

The branches, lumber, and woodchips were all chipped with a residential chipper (Tazz 3" Chipper/Shredder, Earthquake brand, Cumberland, WI, USA), and sieved to two particle size ranges $3.2-6.3 \mathrm{~mm}$ and $6.3-13 \mathrm{~mm}$. These size ranges were smaller than the 25 to $51 \mathrm{~mm}$ effective diameter recommended for use in denitrifying bioreactors (USDA NRCS 2020) but provided a sufficient woodchip supply within uniform size ranges after all were chipped on the residential chipper. Moisture content was performed by drying a sub-set of woodchips at $70^{\circ} \mathrm{C}$ until a constant mass was achieved. Total porosity and bulk density were determined in triplicate by filling glass jars with woodchips in layers, adding water, and weighing the jars after $24 \mathrm{~h}$ after they were topped up with water. Woodchip nutrient content analyses were performed using a wet digestion method (Table S1; Brookside Laboratories Inc., New Bremen, OH, USA) and metal element concentrations were measured by nitric acid-hydrogen peroxide digestion with quantification by inductively coupled plasma mass spectrometry (Institute of Environmental Sustainability, Loyola University of Chicago, IL, USA). Thus, we used total concentrations of $\mathrm{Fe}, \mathrm{Al}, \mathrm{Ca}$, and $\mathrm{Mg}$ as proxies for potential $\mathrm{P}$ removal mechanisms, mediated by sorption via $\mathrm{Fe}$ and $\mathrm{Al}$, and via precipitation by $\mathrm{Ca}$ and $\mathrm{Mg}$. Though $\mathrm{Fe}$ and $\mathrm{Al}$ can engage in precipitation with $\mathrm{P}$, and $\mathrm{Ca}$ and $\mathrm{Mg}$ can sorb $\mathrm{P}$ depending on speciation of these metal elements (e.g., calcium carbonates, iron oxides), for the purpose of explaining potential differences in P removal among woodchips, we relied on total concentrations of these metal elements (Penn et al. 2007). The woodchips were flushed with deionized (DI) water to avoid effects of bioreactor start-up P leaching and then air dried. The flushing was considered complete once woodchip outflow DRP concentrations were below the analytical detection limit of $0.01 \mathrm{mg} \mathrm{P} / \mathrm{L}$ which took no more than 40 days ( 180 cumulative pore volumes).

Three of the woodchip types, poplar, white oak, and the field bioreactor woodchips, in the 3.2-6.3-mm particle size range, were investigated in a post hoc analysis using scanning electron microscopy (SEM) at the University of Illinois Beckman Institute for Advanced Science and Technology. The three woods were selected to give a range across $\mathrm{P}$ removal results and woodchip appearance (e.g., wood color). The woodchips were taken from pre-batch test supplies that had been stored air-dried for approximately a year; the specific woodchips used for the batch tests had been disposed of by the time this analysis was initiated. For the SEM, six woodchips of each type were placed on three separate aluminum disks covered in carbon tape. The disks were sputter-coated with a thin layer of gold-palladium alloy for $70 \mathrm{~s}$ to make the samples electron-conductive for imaging with a Quanta FEG 450 
scanning electron microscope (Thermo Fisher Scientific). Images were taken at $\times 60$ to $\times 12000$ magnification with $10 \mathrm{kV}$ beam voltage and a spot size of $3 \mathrm{~nm}$ for each of the woodchips.

\section{Batch experiments}

Thirteen 72-h batch tests were performed with replication of four (Table 1). The first seven batch tests were conducted to compare individual wood species with varying elemental content of the same particle size $(6.3-13 \mathrm{~mm})$ with DI water dosed to $1.01 \pm 0.01 \mathrm{mg} \mathrm{DRP} / \mathrm{L}$. These first seven tests served as the controls for six additional tests which explored three independent factors: (1) water matrix: P-dosed DI water vs. P-dosed river water; (2) particle size: $3.2-6.3$ vs. $6.3-13 \mathrm{~mm}$; and (3) initial DRP concentration: 1.0 vs. $0.10 \mathrm{mg} / \mathrm{L}$.

For each test, $3 \mathrm{~g}$ of air-dried woodchips was added to 45 $\mathrm{mL}$ of either P-dosed (potassium phosphate monobasic, $\mathrm{KH}_{2} \mathrm{PO}_{4}$ ) DI water or river water in a polypropylene conical tube. Once corrected for moisture content, this resulted in a 16:1-18:1 liquid to solid ratio, loosely following Svensson et al. (2014) who used a ratio of 20:1 in sawdust batch leaching tests. The tubes were secured to a shaker table set at $200 \mathrm{rpm}$ and eleven sample events spanned the $72 \mathrm{~h}(2 \mathrm{~min}$, $10 \mathrm{~min}, 30 \mathrm{~min}, 1 \mathrm{~h}, 3 \mathrm{~h}, 6 \mathrm{~h}, 9 \mathrm{~h}, 24 \mathrm{~h}, 33 \mathrm{~h}, 48 \mathrm{~h}$, and $72 \mathrm{~h}$ ). Each tube was destructively harvested; that is, samples were not collected repeatedly over time from the same tube to avoid changing the liquid to solid ratio over time. Because each of the thirteen tests was performed in quadruplicate, 44 tubes were used for each test (11 sample events $\times$ replication of 4). The tests were performed at $21^{\circ} \mathrm{C}$ except for the river water treatment (see below). All water samples were filtered within 15 min of sample collection $(0.45 \mu \mathrm{m}$ membrane $)$, frozen, and analyzed for DRP (Lachat Quickchem, method 10-115-01-1A instruments, Loveland, CO, USA). Sample $\mathrm{pH}$ was measured within $24 \mathrm{~h}$ of collection ( $\mathrm{pH}$ meter Fisher Scientific AE150, Waltham, MA, USA).

For the three river water treatments (Table 1; poplar, white oak, and hickory), water was sourced from the upper Embarras River near Urbana, IL, in winter (January 2020) and stored at $4{ }^{\circ} \mathrm{C}$ to minimize room temperature-associated changes in the water chemistry. These upper headwaters of the Embarras River are heavily dominated by tile drainage and runoff inputs; thus, this water was intended to be a proxy for the relatively more complex water matrix of tile drainage/ agricultural runoff compared to DI water. The river water had an initial DRP concentration of $0.05 \pm 0.01 \mathrm{mg}$ DRP/L and was dosed to $1.0 \mathrm{mg} \mathrm{DRP} / \mathrm{L}$ using $\mathrm{KH}_{2} \mathrm{PO}_{4}$. However, the dosed river water was mistakenly not shaken before the batch test which resulted in the initial dosed river water samples having concentrations ranging from 0.61 to $0.78 \mathrm{mg}$ $\mathrm{DRP} / \mathrm{L}$. For the particle size testing, two size ranges (3.2-6.3 vs. $6.3-13 \mathrm{~mm}$ for poplar and white oak; Table 1) were selected based on availability once the woods were chipped. The $3 \mathrm{~g}$ of woodchips used in both sets of tests entailed approximately 35 and 20 woodchips in the small $(3.2-6.3 \mathrm{~mm})$ and
Table 1 Treatment descriptions of thirteen 72-h batch tests with dissolved reactive phosphorus (DRP) mean \pm standard deviation concentration reduction and removal per mass dry woodchip. Negative DRP removal values indicate DRP leaching. Each test was performed in quadruplicate $(n=4)$

\begin{tabular}{|c|c|c|c|c|c|}
\hline \multicolumn{4}{|c|}{ Treatment combination } & \multicolumn{2}{|c|}{$P$ removal at test end } \\
\hline Test & Wood & Size & $\begin{array}{l}\text { Initial conc. and } \\
\text { source }\end{array}$ & $\begin{array}{l}\text { Concentration } \\
\text { reduction }\end{array}$ & $\begin{array}{l}\text { mg DRP removed } / \mathrm{kg} \\
\text { woodchip }\end{array}$ \\
\hline \# & Common name & $\mathrm{mm}$ & $\mathrm{mg} \mathrm{P} / \mathrm{L}$ & $\%$ & \\
\hline 1 & Poplar $^{\mathrm{a}}$ & $6.3-13$ & $1.0 \mathrm{DI}$ & $11 \pm 3.2 \% *$ & $2.0 \pm 0.6$ \\
\hline 2 & White oak ${ }^{a}$ & $6.3-13$ & $1.0 \mathrm{DI}$ & $-7.2 \pm 3.2 \% *$ & $-1.2 \pm 0.5$ \\
\hline 3 & Hickory & $6.3-13$ & $1.0 \mathrm{DI}$ & $2.8 \pm 1.2 \% *$ & $0.4 \pm 0.2$ \\
\hline 4 & Cypress & $6.3-13$ & $1.0 \mathrm{DI}$ & $-6.1 \pm 5.0 \% *$ & $-1.0 \pm 0.8$ \\
\hline 5 & Field bioreactor $^{\mathrm{a}}$ & $6.3-13$ & $1.0 \mathrm{DI}$ & $84 \pm 16 \% *$ & $13 \pm 2.5$ \\
\hline 6 & Cedar $^{\mathrm{a}}$ & $6.3-13$ & $1.0 \mathrm{DI}$ & $3.5 \pm 11 \%$ & $0.6 \pm 1.7$ \\
\hline 7 & Maple & $6.3-13$ & $1.0 \mathrm{DI}$ & $7.3 \pm 5.0 \% *$ & $1.1 \pm 0.8$ \\
\hline 8 & Poplar ${ }^{\mathrm{a}}$ & $6.3-13$ & 0.78 River & $87 \pm 3.2 \% *$ & $12 \pm 0.4$ \\
\hline 9 & White oak & $6.3-13$ & 0.68 River & $-36 \pm 17 \% *$ & $-4.1 \pm 1.9$ \\
\hline 10 & Hickory & $6.3-13$ & 0.61 River & $-3.6 \pm 7.9 \%$ & $-0.3 \pm 0.8$ \\
\hline 11 & Poplar & $3.2-6.3$ & $1.0 \mathrm{DI}$ & $24 \pm 2.2 \% *$ & $3.8 \pm 0.4$ \\
\hline 12 & White oak & $3.2-6.3$ & $1.0 \mathrm{DI}$ & $4.3 \pm 6.1 \%$ & $0.8 \pm 1.1$ \\
\hline 13 & Poplar & $6.3-13$ & $0.10 \mathrm{DI}$ & $67 \pm 4.8 \% *$ & $1.2 \pm 0.1$ \\
\hline
\end{tabular}

${ }^{a}$ A subset of batch solutions from one replicate of these tests were analyzed for metals and trace elements by inductively coupled plasma-atomic emission spectrometry

* Indicated the final test concentration mean at $t=72 \mathrm{~h}$ was significantly different (either lower or higher) from the initial test concentration $(a=0.05)$ 
large $(6.3-13 \mathrm{~mm})$ particle size ranges, respectively. These size ranges were smaller than what would be used in a fieldscale bioreactor (USDA NRCS 2020) but the residential chipper provided the most woodchips in these ranges. Finally, one test was performed with a low initial concentration of $0.10 \mathrm{mg}$ DRP/L compared to the other tests' initial concentration of $1.0 \mathrm{mg} \mathrm{DRP} / \mathrm{L}$ (Table 1; poplar).

A subset of batch solutions was selected for additional post hoc trace elements analysis by inductively coupled plasmaatomic emission spectrometry (ICP; Illinois Water Survey, Champaign, IL, USA; US EPA Method 200.7). Due to analytical cost, samples from only five of the thirteen tests were analyzed (Table 1; tests \#1, 2, 5, 6, and 8). These five were selected to give a range across wood types (tests \#1, 2, 5, 6: poplar, white oak, field bioreactor, and cypress chips) and across water matrices (e.g., poplar tests \#1 and \#8). Also considering cost, only one replicate for the selected treatments and only the sample events at $t=0,2 \mathrm{~min}, 10 \mathrm{~min}, 1 \mathrm{~h}, 24$ $\mathrm{h}$, and $72 \mathrm{~h}$ were analyzed. The water samples were stored frozen for approximately 9-12 months prior to this supplemental analysis.

\section{Statistical analyses}

Shapiro-Wilk and Brown-Forsythe tests were used to evaluate normality and equality of variance assumptions, respectively (Sigma Plot version 14.0). The seven wood types were compared using the non-parametric Kruskal-Wallis one-way analysis of variance test (ANOVA; $\alpha=0.05$ ) and then further evaluated using pairwise multiple comparison Tukey tests. For comparisons of discrete categorical variables (e.g., DI vs. river water) and changes in DRP concentration over time (initial vs. final concentration), Student $t$ tests were used when assumptions of normality and equal variance were met. MannWhitney Rank-Sum test was used when the normality assumption was not met, and Welch's $t$ test was used when the assumption of equal variances was not met.

\section{Results}

\section{Elemental and microscopy analyses of wood types}

The woodchips sourced from a surplus pile at a field bioreactor installation site had notably higher $\mathrm{Al}, \mathrm{Fe}$, and $\mathrm{Mg}$, but not $\mathrm{Ca}$, contents compared to the other woods of specific species (Fig. 1). Visual observation showed that they were darker than the other woodchips possibly indicating that there was soil mixed in with these woodchips (Fig. S1). The white oak woodchips also had relatively high values for these elements and contained the highest calcium content of the seven treatments by nearly twice $(1720 \mathrm{mg} \mathrm{Ca} / \mathrm{kg})$. The poplar and hickory woodchips were relatively low in all four elements. These total metal contents allowed an initial assessment and comparison between wood types, although it is recognized that the potential reactivity of $\mathrm{P}$ sorbing media may be better characterized by amorphous $\mathrm{Fe}$ or $\mathrm{Al}$ oxides or water-soluble $\mathrm{Ca}$ (Penn et al. 2007; Qin et al. 2018).

The darker color of the field bioreactor woodchips was additionally explored using scanning electron microscopy which showed these woodchips to be relatively dirty and degraded (Fig. 2a and b). Some fungal hyphae were visible (Fig. 2a, white-dashed circle around spaghetti-like strings) but the more notable feature of these woodchips was their broken edges (Fig. 2a and b, arrows) and degradation of vascular structures. In contrast, the poplar and oak woodchips still exhibited tracheid and vessel cylindrical elements (Fig. 2c and d). The oak woodchips were widely covered with fungal mycelia (Fig. 2d, mass of white strings) much more so than the other two wood types on which scanning electron microscopy was performed. The chipped poplar lumber was sold as untreated lumber, but it was devoid of fungus and no bacteria were observed. Of the three types, bacteria were primarily observed on the white oak woodchips (Fig. S2).

\section{Batch tests}

\section{Wood types}

Six of the seven wood types exhibited a significant change in batch solution DRP concentration over the 72-h test with four of those six providing 2.8-84\% reductions in DRP concentration (field bioreactor, poplar, maple, hickory; Table 1, Fig. 3). The $84 \%$ DRP concentration reduction by the field bioreactor woodchips was significantly greater than the concentration changes caused by the white oak and cypress $(p=0.006$ and 0.005 , respectively, for pairwise multiple comparison Tukey tests) and was not significantly different from the four other treatments. The net DRP concentration changes for the poplar, white oak, hickory, cypress, cedar, and maple ranged from $11 \%$ reduction to $7.2 \%$ leached (Table 1 ) but were not significantly different from each other ( $p$ values ranging from 0.234 to 1.0 for pairwise Tukey tests).

Cypress and white oak increased solution DRP concentration. In addition to having relatively high concentrations of metals known to sorb P (Fig. 1), the white oak also had a high $\mathrm{P}$ content of $0.035 \%$ compared to the other woods which ranged from $<0.01$ to $0.031 \% \mathrm{P}$ (Table S1). Most of the batch solution samples of these first seven tests had $\mathrm{pH}$ values below 6.0 (Fig. 4). The white oak leachate, which increased from $\mathrm{pH}$ of 6.51 to 7.29 by the end of the 72-h test, was the notable exception. The deionized tap in the lab provided water at a $\mathrm{pH}$ of $5.73 \pm 0.07$ and low values similar to this study $(<\mathrm{pH} 6.0)$ have been previously reported in woody media batch studies (Díaz-García et al. 2020; McLaughlan and Al-Mashaqbeh 2009). Cedar was the only wood type of the initial seven that 
Fig. 1 Elemental content for relevant phosphorus-sorptionrelated metals for seven wood types used in batch tests

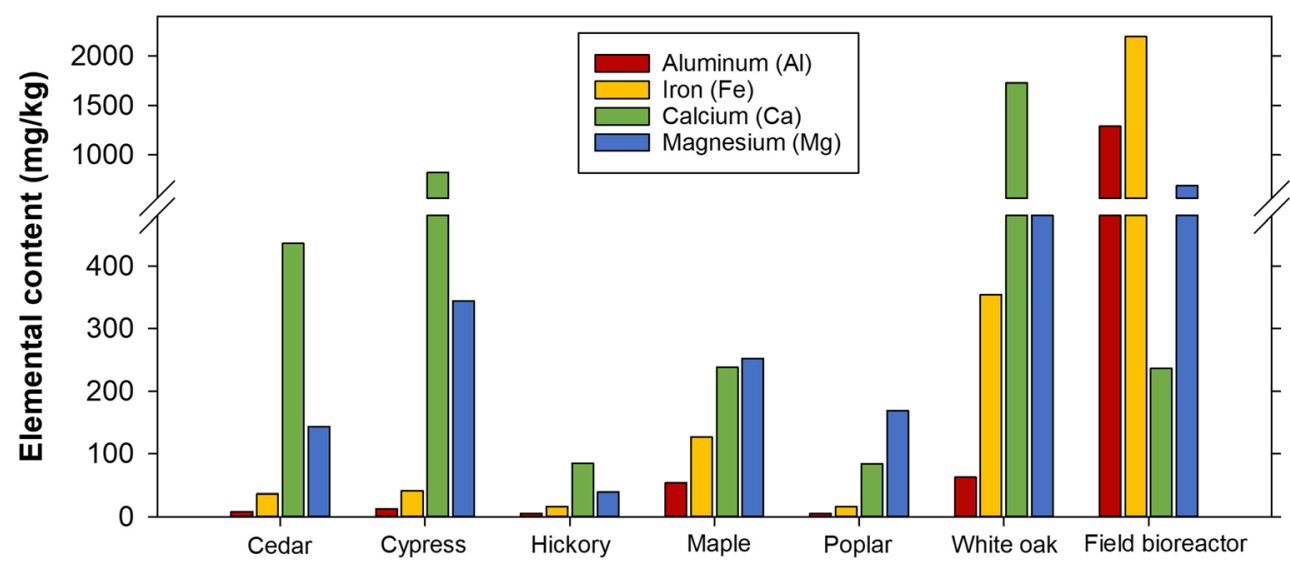

did not significantly change the batch solution DRP concentration over the $72 \mathrm{~h}$ (Table 1; based on Welch's $t$ test comparing concentrations at initial and final sample events; $p=$ $0.555)$.

There was a release of $\mathrm{Ca}$ into solution by the field bioreactor woodchips within $12 \mathrm{~h}$ and, even more notably, by the white oak within $1 \mathrm{~h}$ (Fig. 5a). The field bioreactor woodchips were the only treatment of the five tested using ICP that released $\mathrm{Mg}, \mathrm{Al}$, or $\mathrm{Fe}$ into the batch leachate (Figs. 5b-d).

\section{Water matrix: deionized vs. river water}

Changes in DRP concentrations were similar for batch tests performed with P-dosed river water compared to P-dosed DI water $(p=0.583$; river and DI treatment means; $16 \pm 55 \%$ and $2.1 \pm$ $8.0 \%$, respectively). However, this comparison was confounded by differences in both water temperature and initial $\mathrm{P}$ concentration. Since the relatively cool river water $\left(4{ }^{\circ} \mathrm{C}\right)$ acclimated to room temperature $\left(20^{\circ} \mathrm{C}\right)$ within approximately $3 \mathrm{~h}$, it is possible that microbial processes may have been initially slowed, but

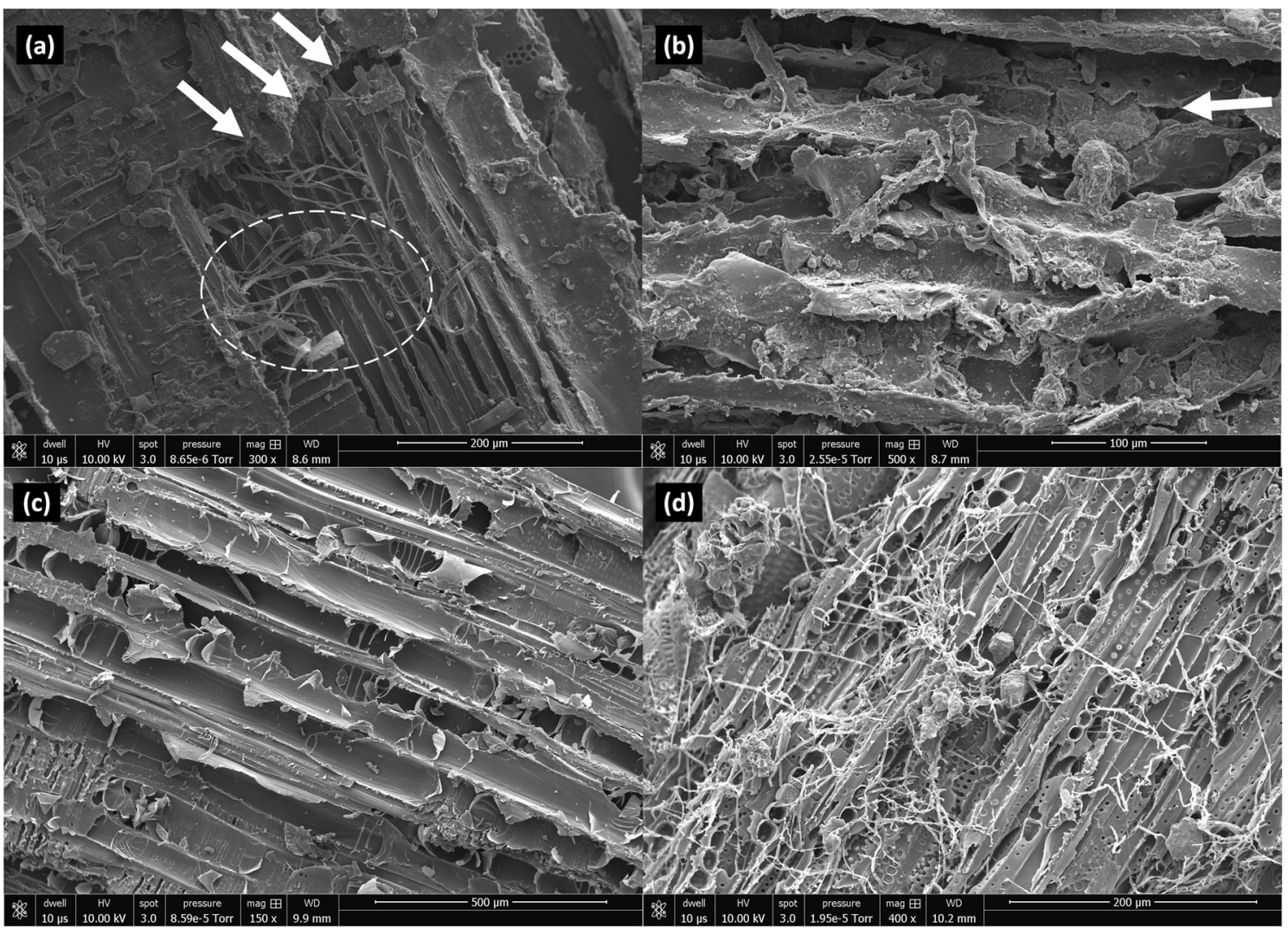

Fig. 2 Scanning electron microscopy (SEM) images of initial field bioreactor $(\mathbf{a}, \times 300 ; \mathbf{b}, \times 500)$, poplar $(\mathbf{c}, \times 150)$, and white oak $(\mathbf{d}, \times 400)$ woodchips prior to their use in batch tests. The arrows indicate degraded and broken edges and the dashed circle highlights fungal hyphae, both on the field bioreactor woodchips 
Fig. 3 Mean \pm standard deviation dissolved reactive phosphorus wood types in 72-h batch tests ( $n$ $=4)$. Test \# in the legend refers to the test numbers in Table 1 . The initial sample event at $t=0$ was set at $0.01 \mathrm{~h}$ due to the logarithmic $x$-axis (DRP) concentrations for seven

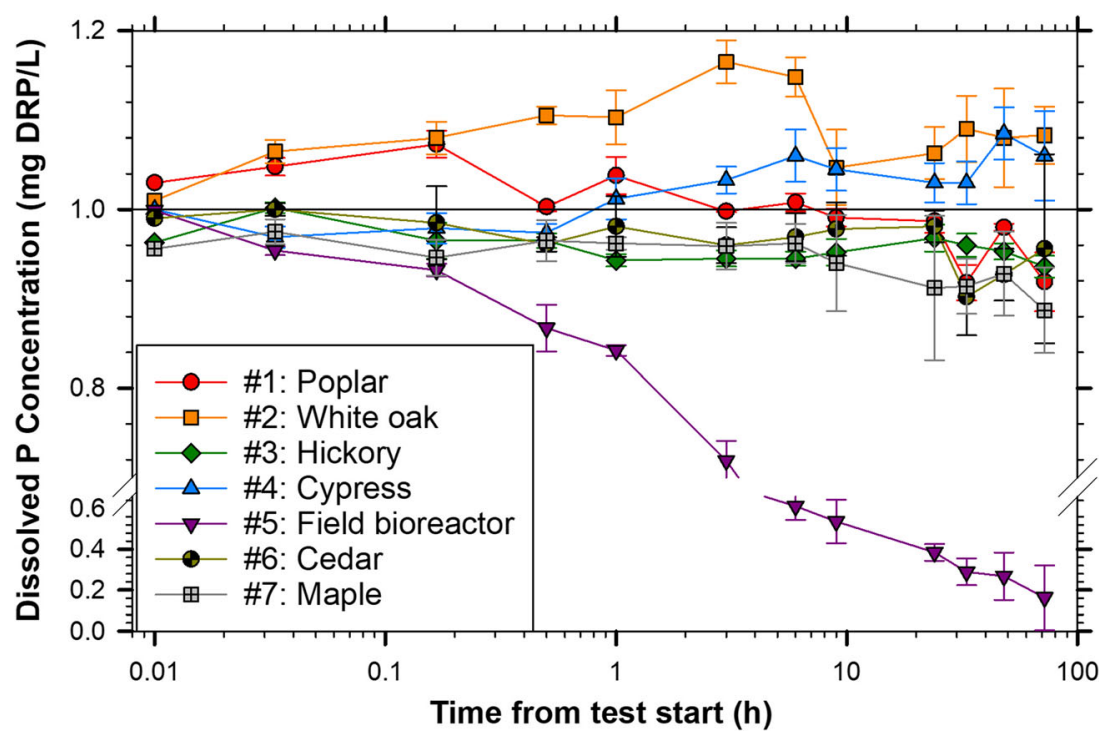

Particle size: $3.2-6.3$ vs. $6.3-13 \mathrm{~mm}$ woodchips

subsequent warming contributed to the observed decrease in DRP later in the tests. The second difference was because the river water treatments were mistakenly not shaken prior to the start of testing, and the initial concentrations for those three river water treatments ranged from 0.61 to $0.78 \mathrm{mg} \mathrm{DRP} / \mathrm{L}$ instead of the correctly calculated target of $1.0 \mathrm{mg}$ DRP/L (Fig. 6a). Solution DRP concentrations increased for all the river water treatments until 6 to $9 \mathrm{~h}$, at which point DRP concentrations declined. If concentration reductions assessed over the entire test were calculated using the correct $1.0 \mathrm{mg} \mathrm{DRP} / \mathrm{L}$ as the initial concentration, the poplar, white oak, and hickory would have provided $90 \pm 2.6,12 \pm 11$, and $39 \pm 4.6 \% \mathrm{DRP}$ concentration reductions, respectively, rather than the $87 \pm 3.2,-36 \pm 17$, and $-3.6 \pm 7.9 \%$ shown in Table 1. Assuming the correct initial concentration (after mixing) would have resulted in a significant difference between the river- and DI-dosed treatments $(p<$ 0.001 ; river and DI treatment means, $47 \pm 34 \%$ and $2.1 \pm$ $8.0 \%$, respectively).

Fig. 4 Mean \pm standard deviation batch solution $\mathrm{pH}$ at each sample event for ten 72-h batch tests where P-dosed deionized and Pdosed river water were used $(n=$ 4). Test \# in the legend refers to the test numbers in Table 1
Across wood types, smaller woodchips removed sixfold more DRP compared to larger woodchips, with mean reductions in DRP concentration of $14 \pm 11$ vs. $1.8 \pm 10 \%$, respectively ( $p=$ 0.050 ; Fig. 6b). Both chemical sorption and microbial immobilization mechanisms of $\mathrm{P}$ removal can be functions of surface area. Regardless, the smaller woodchip size tested here is not recommended for full-size bioreactor applications due to possible restriction of water flow (Van Driel et al. 2006).

\section{Low and high P-dosed initial concentration}

The lower initial concentration of $0.10 \mathrm{mg}$ DRP/L resulted in significantly greater DRP concentration reductions than the higher initial concentration of $1.0 \mathrm{mg}$ DRP/L (67 and $11 \%$ DRP removal, respectively, $p<0.001$; Table 1; Fig. 6c). However, when expressed on a woodchip mass removal basis,

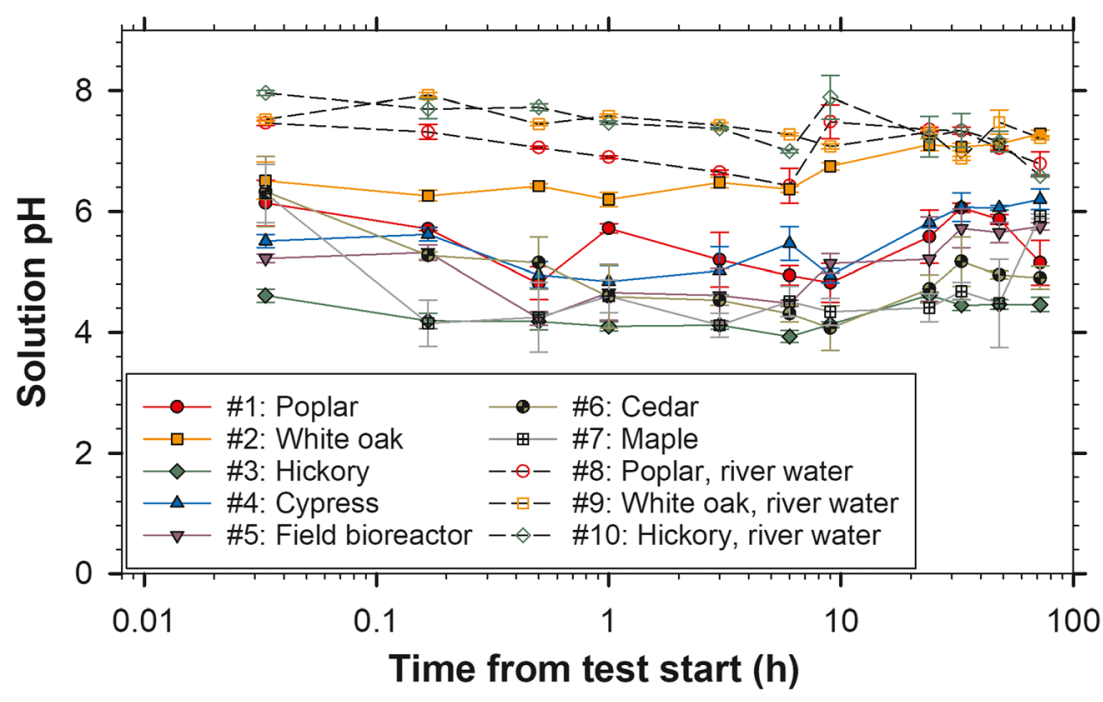



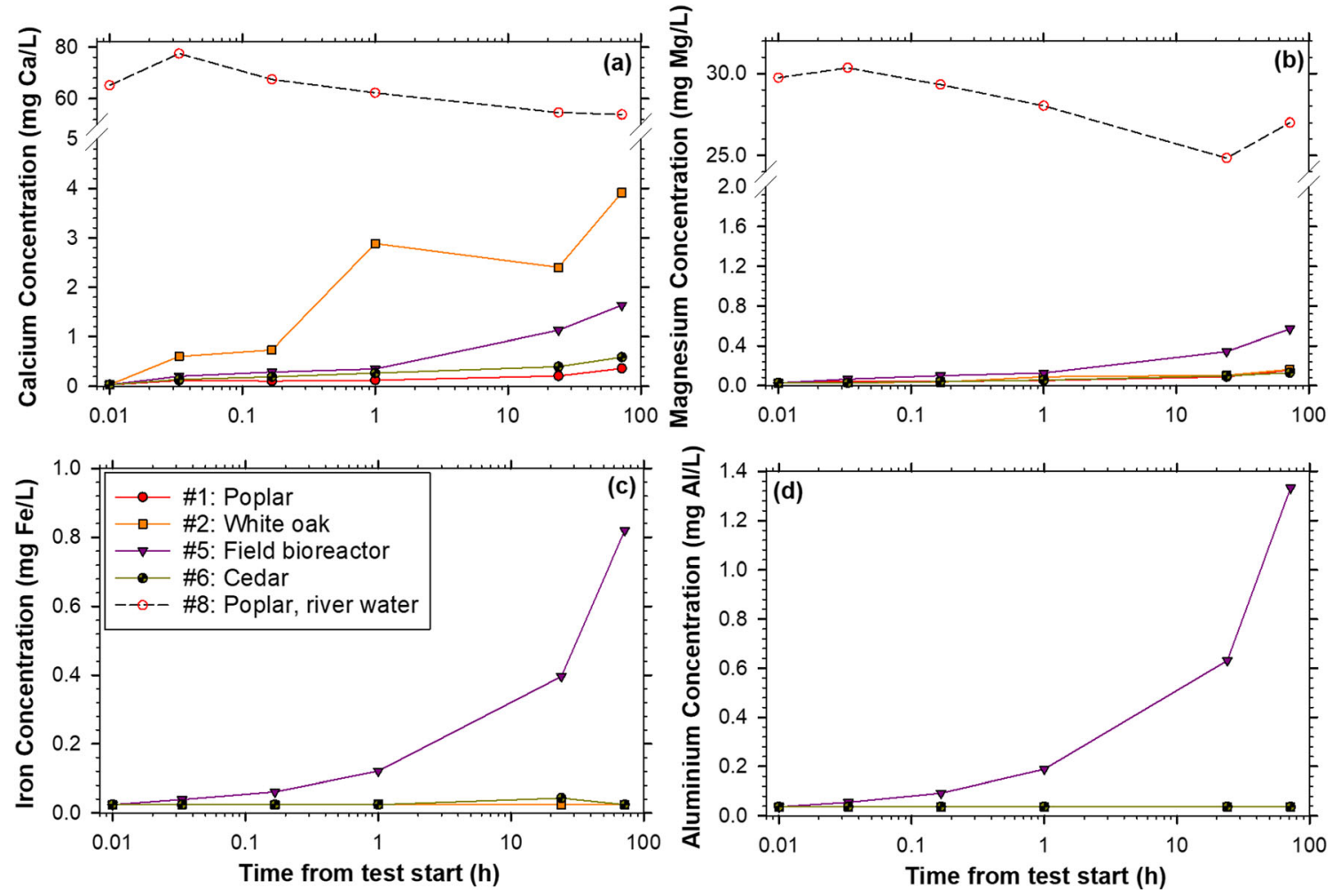

Fig. 5 Calcium (a), magnesium (b), iron (c), and aluminum (d) concentrations for five treatments tested during 72-h batch tests $(n=1$, only one replicate was analyzed). Test \# in the legend refers to the test

the higher dosing test resulted in $2.0 \pm 0.6 \mathrm{mg} \mathrm{P}$ removed per $\mathrm{kg}$ woodchip compared to the lower dose test for which only $1.2 \pm 0.1 \mathrm{mg} / \mathrm{kg}$ was removed.

\section{Discussion}

\section{Phosphorus removal by woodchips: proof of concept}

The field bioreactor woodchips provided the greatest DRP removal $(13 \pm 2.5 \mathrm{mg} \mathrm{P}$ removed $/ \mathrm{kg}$ woodchip $)$ and concentration reduction (84\%) during the first seven tests where wood types were compared (Table 1). The $\mathrm{Al}$ and $\mathrm{Fe}$ contents of those woodchips were notably high (Fig. 1) which suggested that, to the extent that these are present in amorphous (hydr)oxide forms, sorption reactions rather than $\mathrm{Ca} / \mathrm{Mg}$ associated precipitation may have been the more dominant chemical removal mechanism for those chips. However, as we did not quantify contents of reactive $\mathrm{Fe}$ and $\mathrm{Al}$ (e.g., (hydr)oxide minerals), nor the proportion of total $\mathrm{Ca}$ and $\mathrm{Mg}$ in water soluble form, which would engage in precipitation reactions, full certainty in ascribing mechanisms of $\mathrm{P}$ removal are not possible. Additionally, ligand exchange sorption reactions are relatively fast (e.g., $<20 \mathrm{~min}$; Penn et al. 2007; Stoner et al. 2012), and the field bioreactor woodchips reduced the DRP concentrations consistently over the entire numbers in Table 1. $t=0$ was set at $0.01 \mathrm{~h}$ due to the logarithmic $x$-axis. Note the $y$-axis breaks in panels $\mathbf{a}$ and $\mathbf{b}$

72-h test. Such increasing DRP removal over this timeframe could have been because there was an abundance of $\mathrm{P}$ sorption sites which were never saturated. The possibility of microbial $P$ removal (i.e., microbial growth which requires phosphate; Hua et al. 2016) also existed especially considering when these chips could have been relatively more inoculated given their source. However, bacteria were not widely detected on these woodchips using scanning electron microscopy and such removal predominantly occurs under aerobic conditions which would have been most likely early in the tests (dissolved oxygen and redox potential were not measured).

The solution $\mathrm{pH}$ provided additional evidence that if chemical P sorption was occurring, it would be associated with $\mathrm{Al}$ or $\mathrm{Fe}$ rather than $\mathrm{Ca}$ or $\mathrm{Mg}$ as most of the batch leachate samples of the first seven tests had $\mathrm{pH}$ values below 6.0 (Fig. 4; except the white oak treatment). Phosphorus precipitation with $\mathrm{Ca}$ and $\mathrm{Mg}$ materials is most effective at a $\mathrm{pH}$ range of 6.0 to 7.5, whereas $\mathrm{Fe}$ and $\mathrm{Al}$-based $\mathrm{P}$ sorption is optimized under acidic conditions (Penn et al. 2007; Qin et al. 2018).

The field bioreactor woodchip's leachate water chemistry containing $\mathrm{Al}$ and $\mathrm{Fe}$ reflected the elemental analysis of these woodchips (Fig. 1; Figs. 5c and d). Lindholm-Lehto et al. (2020) reported peak Al concentrations in woodchip (silver birch, Betula pendula) bioreactor outflows of $0.055 \mathrm{mg} \mathrm{Al} / \mathrm{L}$. Lepine et al. (2020) observed a higher peak concentration of 
Fig. 6 Mean \pm standard deviation dissolved reactive phosphorus (DRP) concentrations for testing with P-dosed deionized water vs. P-dosed river water (a), 3.2-6.3 (small) vs. 6.3-13 mm woodchip particle size (b), and low vs. high (0.10 vs. $1.0 \mathrm{mg}$ DRP/L) initial concentrations over 72-h batch tests $(n=4)$. Test \# in the legends refers to the test numbers in Table 1. $t=0$ was set at $0.01 \mathrm{~h}$ due to the logarithmic $x$-axis. The differences between treatment means were not significant for the river vs. DI treatment ( $p=0.583$ ); significant for the small vs. larger woodchip size ( $p=0.050)$; and significant for the low vs. high initial P concentration $(p<0.001)$
Time from test start (h)
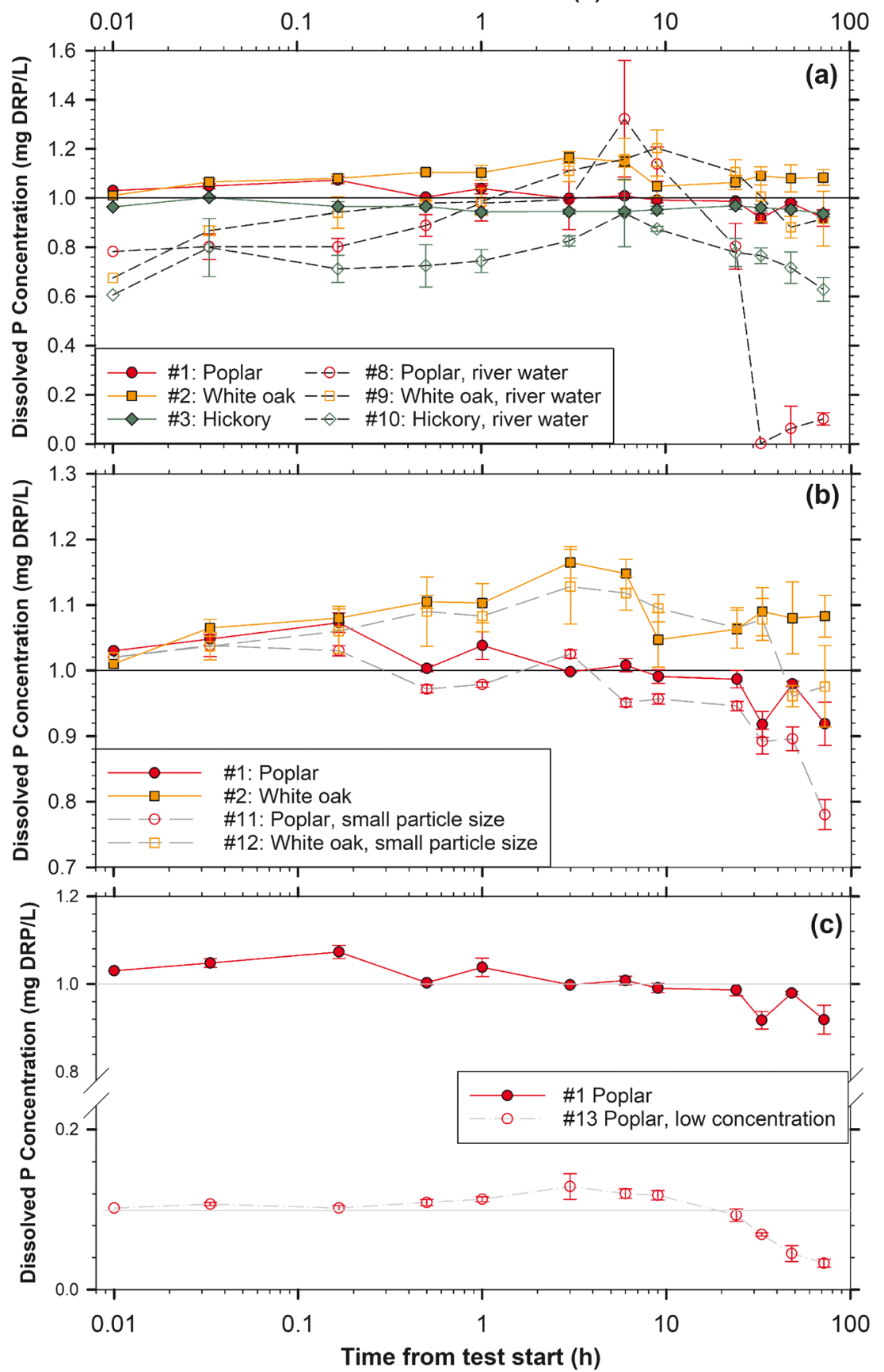

$0.84 \mathrm{mg} \mathrm{Al} / \mathrm{L}$ in column tests with maple (Acer platanoides) and ash (Fraxinus americana) woodchips. Though batch solution Al was below the detection limit of $0.037 \mathrm{mg} / \mathrm{L}$ for nonweathered (i.e., "raw") woodchips, the field bioreactor woodchip leachate reached a maximum of $1.33 \mathrm{mg} \mathrm{Al} / \mathrm{L}$. Similar to Al, nearly all the batch solutions tested below the detection limit for $\mathrm{Fe}(<0.024 \mathrm{mg} / \mathrm{L})$, except the field bioreactor treatment which peaked at $0.82 \mathrm{mg} / \mathrm{L}$. Rivas et al. (2020) reported an increase in Fe across a bioreactor in New Zealand treating dairy pasture drainage (inflow and outflow; $0.022 \pm$ 0.019 and $0.219 \pm 0.326 \mathrm{mg} \mathrm{Fe} / \mathrm{L}$, respectively). In the same year, there was 89\% DRP removal across the bioreactor (inflow and outflow, $0.109 \pm 0.195$ and $0.011 \pm 0.007 \mathrm{mg} \mathrm{DRP} /$ L). In the current study, the analysis of soluble metals in the batch solution, particularly for the field bioreactor woodchips, supported the possibility of DRP removal via chemical mechanisms.

The set of tests performed with dosed river water added more nuances to the possible sorption of DRP within a woodchip bioreactor. Calcium, magnesium (Fig. 5a and b), sodium, potassium, and sulfur (Figs. S3a-c; Table S2) concentrations were generally an order of magnitude higher in the 
one river water treatment compared to the tests where dosed DI water was used. Additionally, the river water batch tests had a higher mean solution $\mathrm{pH}$ compared to the DI tests $(7.3 \pm$ 0.37 vs. $4.9 \pm 0.83 ; n=33$ and 153 , respectively). The DRP mass removal achieved by the poplar woodchips in the dosed river water was the second greatest across all seventeen tests $(12 \pm 0.4 \mathrm{mg} / \mathrm{kg}$; Table 1$)$, even though the metal element content of the poplar woodchips was markedly low. It is possible that the relatively high metal element concentrations of the river water, which was used as a proxy for drainage water that would be treated in a bioreactor, masks the effect of lower concentrations of metal elements derived from the woodchips.

Water chemistry and microbiology are inexorably linked, and while the river water included naturally high concentrations of micronutrients, it also likely contained a microbial community different from the DI water. These river water tests were not designed to partition any observed DRP removal into sorption vs. microbial pathways, although microbial P uptake could have been possible. The relative possibility for and contribution of microbial P uptake vs. P sorption mechanisms in woodchip bioreactors is an area suggested for further research. Both wood media and water matrices are highly complex in this application in that while chemical sorption due to woodchip elemental content may be possible, it would likely be one of a variety of mechanisms at play in more real-world bioreactor settings.

\section{Wood composition and $P$ removal}

Wood elemental content varies based on factors such as tree species, age, growth conditions, and part of the tree (Koch 1985; Ovington 1959). In addition, the woods tested here spanned a variety of sources (lumber, fallen branches, commercially available chips) and types (softwood gymnosperms, hardwood angiosperms). While there is a range of what might be expected for elemental content of wood, the range across treatments presented a real-world scenario of the variability of woods available for bioreactors.

The wood elemental analysis and associated solution water chemistry of the field bioreactor woodchips may have been influenced by attached soil particles. Someshwar (1996) reported that soil could indeed become attached to wood (e.g., sand imbedded in bark). It was also possible that the brownish color of the field bioreactor woodchips may have been due to the decay of the wood or due to a brown rot fungus (Schwarze 2007). There was little evidence of active fungal colonization under the scanning electron microscope, but the broken and degraded vascular structures were notable on these chips compared to the other two viewed in this analysis (Fig. 2). Moreover, the field bioreactor woodchips were reportedly mainly hardwood (angiosperm) and brown rots are more associated with softwood species (gymnosperm, conifers; Schwarze 2007).
Beyond that unique field-sourced treatment, the chipped white oak deadfall branches had the highest Ca content (Fig. 1) and leached a notable amount of $\mathrm{Ca}$ into solution (Fig. 5a). Lindholm-Lehto et al. (2020) observed Ca concentrations in birch wood bioreactor outflows initially greater than $10 \mathrm{mg}$ $\mathrm{Ca} / \mathrm{L}$ which flushed to less than $5 \mathrm{mg} \mathrm{Ca} / \mathrm{L}$. This was in good agreement with the end of test concentrations here of $3.9 \mathrm{mg}$ $\mathrm{Ca} / \mathrm{L}$ from white oak, with concentrations ranging from 2 to $3 \mathrm{mg} \mathrm{Ca} / \mathrm{L}$ between 1 and $24 \mathrm{~h}$. Calcium and $\mathrm{Mg}$ must be released into solution for $\mathrm{P}$ precipitation to occur (Penn et al. 2007), and this timeframe ( 1 to $24 \mathrm{~h}$ ) is a realistic bioreactor retention time indicating that it could be possible for $\mathrm{Ca}$ from woodchips to precipitate $\mathrm{P}$ in this application.

The use of oak woodchips in denitrifying bioreactors is restricted by the USDA NRCS Conservation Practice Standard due to this wood's high tannin content which was assumed to negatively impact the denitrifying community and/or the downstream aquatic environment (USDA NRCS 2020). Despite this concern, oak wood may inherently support greater denitrification potential than other woods (Wickramarathne et al. 2021). Under the scanning electron microscope, the white oak presented a distinctive case of fungal colonization as nearly all the images showed large masses of hyphae (Fig. 2d). The uniqueness of oak in bioreactor applications was further confirmed here by the leachate $\mathrm{Ca} d y-$ namics, proliferate fungal colonization, high solution $\mathrm{pH}$ (Fig.4), and DRP leaching even after pre-test flushing (Fig. 3). It is important to select woodchips for bioreactors to provide suitable $\mathrm{N}$ removal and also avoid pollution swapping.

The hickory and poplar woodchips were both chipped from store-bought lumber and both were considered to have relatively low metal cation content. Pettersen (1984) reported two poplar species contained $800-1200 \mathrm{mg} \mathrm{Ca} / \mathrm{kg}$ and 270 $290 \mathrm{mg} \mathrm{Mg} / \mathrm{kg}$; these values were much higher than the chipped poplar lumber used here which contained $84 \mathrm{mg}$ $\mathrm{Ca} / \mathrm{kg}$ and $169 \mathrm{mg} \mathrm{Mg} / \mathrm{kg}$. Nevertheless, the poplar woodchips resulted in DRP removal across nearly all tests (Table 1; 87, 67, 24, and 11\% in four tests). Relatively consistent DRP removal by wood with comparatively low metal element content highlights that $\mathrm{P}$ removal is not reducible to woodchip composition alone and underscores the complexity of P-wood interactions specific to tree species.

\section{Scalability and application}

Denitrifying woodchip bioreactors treating subsurface drainage water would generally be subjected to DRP concentrations much lower than the $1.0 \mathrm{mg} \mathrm{DRP} / \mathrm{L}$ used as the initial concentration in most of the tests here. For example, the 25 th and 75th percentiles of more than 400 site-years of drainage dissolved P concentrations were 0.016 and $0.064 \mathrm{mg} \mathrm{DP} / \mathrm{L}$, respectively, in a large-scale review by Hertzberger et al. (2019). Only one woodchip type was tested under the low concentration conditions (test \#13; poplar with $0.10 \mathrm{mg}$ 
$\mathrm{DRP} / \mathrm{L}$ ), but it was notable that the final DRP concentration achieved with this low range test was $0.033 \pm 0.005 \mathrm{mg} \mathrm{DRP/}$ L (Fig. 6c). The relatively high percentage concentration reduction (67\%, third highest of the 13 tests) and notable mass removal $(1.2 \pm 0.1 \mathrm{mg} / \mathrm{kg})$ of this low range test supported the value of monitoring DRP dynamics at field-scale bioreactors, as subsurface drainage concentrations tend to be low but can be above values thought to lead to eutrophication (e.g., > $0.038 \mathrm{mg} \mathrm{TP} / \mathrm{L}$ for lakes in the US Corn Belt and Northern Great Plains; USEPA 2002).

Using the range of observed mass removals of 0.4 to $13 \mathrm{mg}$ $\mathrm{DRP} / \mathrm{kg}$ and assuming an average bioreactor size of $100 \mathrm{~m}^{3}$ (following Christianson et al. 2021) and bulk density of 200 $\mathrm{kg} / \mathrm{m}^{3}$ (e.g., Goodwin et al. 2015) would result in DRP removals of 8.0 to $260 \mathrm{~g}$ at the field scale. Assuming an average drainage area of 20 ha for this hypothetical bioreactor would result in $\mathrm{P}$ loss reductions 0.40 to $13 \mathrm{~g} \mathrm{DRP} / \mathrm{ha}$, albeit this would be on a one-time basis and the ultimate fate of this $\mathrm{P}$ is still unclear. However, at least two field bioreactors have provided DRP removal in their second year of operation (that is, beyond the first year of operation; Dougherty 2018; Rivas et al. 2020) meaning that additional field studies and laboratory mechanistic studies may help further inform the extent of this potential benefit.

\section{Conclusion}

The significant differences in DRP concentrations over the batch tests demonstrated the possibility for woodchips to influence $\mathrm{P}$ dynamics in a bioreactor, both positively and negatively. Any consistent DRP removal would be an important added value benefit of this denitrifying technology. Woodchips that were sourced from the field and contained the highest aluminum and iron content provided the most dissolved P removal, but woodchips with very low metal content provided the second highest removal when they were tested with P-dosed river water. While the amount and speciation of metals in P sorbing media are important, DRP removal will also be influenced by water chemistry (e.g., the water's $\mathrm{pH}$, buffering capacity). It is likely that any possible DRP removal by woodchips in a denitrifying bioreactor is not reducible to woodchip composition alone as there would be a variety of mechanisms at play in real-world bioreactor settings with complex water matrices. While bioreactor DRP removal is likely to be small in magnitude, observed $\mathrm{P}$ removals here combined with the relatively few technologies for mitigating dissolved $\mathrm{P}$ once it is in agricultural runoff and effluents and the relatively low concentrations of $\mathrm{P}$ known to cause eutrophication in freshwater makes any such contribution to $\mathrm{P}$ loss reduction important, especially when this is an added value.
Supplementary Information The online version contains supplementary material available at https://doi.org/10.1007/s11356-021-15835-w.

Author contribution APSBB performed the batch experiments, initial data analysis, and wrote the original draft; AM provided reviewing and editing; RACC provided reviewing and editing; and LEC provided formal analysis, funding acquisition, reviewing and editing, and project administration. All authors have given approval to the final version of the manuscript.

Funding This work was supported by the Illinois Nutrient Research and Education Council (NREC 2017-4-360498-302); project NR185A12XXXXC004 CESU under the Great Rivers Umbrella Agreement 68-3A75-18-518 504 (USDA NRCS); and USDA Hatch project ILLU-802-925.

Availability of data and materials The datasets used and/or analyzed during the current study are available from the corresponding author on reasonable request.

\section{Declarations}

Ethics approval and consent to participate Not applicable.

Consent for publication Not applicable.

Competing interests The authors declare no competing interests.

Open Access This article is licensed under a Creative Commons Attribution 4.0 International License, which permits use, sharing, adaptation, distribution and reproduction in any medium or format, as long as you give appropriate credit to the original author(s) and the source, provide a link to the Creative Commons licence, and indicate if changes were made. The images or other third party material in this article are included in the article's Creative Commons licence, unless indicated otherwise in a credit line to the material. If material is not included in the article's Creative Commons licence and your intended use is not permitted by statutory regulation or exceeds the permitted use, you will need to obtain permission directly from the copyright holder. To view a copy of this licence, visit http://creativecommons.org/licenses/by/4.0/.

\section{References}

Bell N, Cooke RA, Olsen T, David MB, Hudson R (2015) Characterizing the performance of denitrifying bioreactors during simulated subsurface drainage events. J Environ Qual 44(5):1647-1656

Cameron SG, Schipper LA (2010) Nitrate removal and hydraulic performance of organic carbon for use in denitrification beds. Ecol Eng 36(11):1588-1595

Choudhury T, Robertson WD, Finnigan DS (2016) Suspended sediment and phosphorus removal in a woodchip filter treating agricultural washwater. J Environ Qual 45(3):796-802

Christianson L, Cooke R, Hay C, Helmers M, Feyereisen G, Ranaivoson A, McMaine J, McDaniel R, Rosen T, Pluer W, Schipper L, Dougherty H, Robinson R, Layden I, Irvine-Brown S, Manca F, Dhaese K, Nelissen V, von Ahnen M (2021) Effectiveness of denitrifying bioreactors on water pollutant reduction from agricultural areas. Trans ASABE 64(2):641-658 
Díaz-García C, Martínez-Sánchez JJ, Álvarez-Rogel J (2020) Bioreactors for brine denitrification produced during polluted groundwater desalination in fertigation areas of SE Spain: batch assays for substrate selection. Environ Sci Pollut Res 27:34388-34397

Dougherty H (2018) Hydraulic evaluation of a denitrifying bioreactor with baffles. University of Illinois, Urbana

Goodwin GE, Bhattarai R, Cooke R (2015) Synergism in nitrate and orthophosphate removal in subsurface bioreactors. Ecol Eng 84: 559-568

Healy MG, Ibrahim TG, Lanigan GJ, Serrenho AJ, Fenton O (2012) Nitrate removal rate, efficiency and pollution swapping potential of different organic carbon media in laboratory denitrification bioreactors. Ecol Eng 40:198-209

Hertzberger A, Pittelkow CM, Harmel RD, Christianson LE (2019) The MANAGE Drain Concentration database: a new tool compiling North American drainage nutrient concentrations. Ag Water Man 216:113-117

Hua G, Salo MW, Schmit CG, Hay CH (2016) Nitrate and phosphate removal from agricultural subsurface drainage using laboratory woodchip bioreactors and recycled steel byproduct filters. Water Res 102:180-189

Husk BR, Sanchez JS, Anderson BC, Whalen JK, Wootton BC (2018) Removal of phosphorus from agricultural subsurface drainage water with woodchip and mixed-media bioreactors. J Soil Water Conserv 73(3):265-275

Koch P (1985) Utilization of hardwoods growing on southern pine sites; Agriculture Handbook No. 605. United States Department of Agriculture, Forest Service (ed), Washington DC

Lepine C, Christianson L, Soucek D, McIsaac G, Summerfelt S (2020) Metal leaching and toxicity of denitrifying woodchip bioreactor outflow - potential reuse application. Aquac Eng 93:102129

Lindholm-Lehto P, Pulkkinen J, Kiuru T, Koskela J, Vielma J (2020) Water quality in recirculating aquaculture system using woodchip denitrification and slow sand filtration. Environ Sci Pollut Res 27(14):17314-17328

McLaughlan RG, Al-Mashaqbeh O (2009) Effect of media type and particle size on dissolved organic carbon release from woody filtration media. Bioresour Technol 100:1020-1023

Ovington JD (1959) The calcium and magnesium contents of tree species crown in close stands. New Phytol 58(2):164-175

Penn C, McGrath J, Bowen J, Wilson S (2014) Phosphorus removal structures: a management option for legacy phosphorus. J Soil Water Conserv 69(2):51A-56A

Penn CJ, Bryant RB, Kleinman PJA, Allen AL (2007) Removing dissolved phosphorus from drainage ditch water with phosphorus sorbing materials. J Soil Water Conserv 62(4):269-276

Pettersen R (1984) The chemistry of solid wood, pp. 57-126, American Chemical Society.

Qin Z, Shober AL, Scheckel KG, Penn CJ, Turner KC (2018) Mechanisms of phosphorus removal by phosphorus sorbing materials. J Environ Qual 47(5):1232-1241

Rivas A, Barkle G, Stenger R, Moorhead B, Clague J (2020) Nitrate removal and secondary effects of a woodchip bioreactor for the treatment of subsurface drainage with dynamic flows under pastoral agriculture. Ecol Eng 148:105786

Schipper LA, Robertson WD, Gold AJ, Jaynes DB, Cameron SC (2010) Denitrifying bioreactors-an approach for reducing nitrate loads to receiving waters. Ecol Eng 36:1532-1543

Schwarze FWMR (2007) Wood decay under the microscope. Fungal Bio Rev 21(4):133-170

Sharrer K, Christianson LE, Lepine C, Summerfelt ST (2016) Modeling and mitigation of denitrification 'woodchip' bioreactor phosphorus releases during treatment of aquaculture wastewater. Ecol Eng 93: 135-143

Someshwar AV (1996) Wood and combination wood-fired boiler ash characterization. J Environ Qual 25(5):962-972

Stoner D, Penn C, McGrath J, Warren J (2012) Phosphorus removal with by-products in a flow-through setting. J Environ Qual 41(3):654 663

Svensson H, Marques M, Kaczala F, Hogland W (2014) Leaching patterns from wood of different tree species and environmental implications related to wood storage areas. Water Environ J 28(2):277284

United States Department of Agriculture Natural Resources Conservation Service [USDA NRCS] (2020) Conservation Practice Standard Denitrifying Bioreactor Code 605. United States Department of Agriculture Natural Resources Conservation Service, Washington

USEPA (2002) Summary table for the nutrient criteria documents for TP LIMITS (http://www2.epa.gov/nutrient-policy-data/ecoregionalcriteria-documents). United States Environmental Protection Agency., Washington

Van Driel PW, Robertson WD, Merkley LC (2006) Denitrification of agricultural drainage using wood-based reactors. Trans ASABE 49(2):565-557

von Ahnen M, Pedersen PB, Dalsgaard J (2018) Performance of full-scale woodchip bioreactors treating effluents from commercial RAS. Aquac Eng 83:130-137

Warneke S, Schipper LA, Bruesewitz DA, McDonald I, Cameron S (2011) Rates, controls and potential adverse effects of nitrate removal in a denitrification bed. Ecol Eng 37(3):511-522

Weigelhofer G, Hein T (2015) Efficiency and detrimental side effects of denitrifying bioreactors for nitrate reduction in drainage water. Environ Sci Pollut Res 22(17):13534-13545

Wickramarathne N, Foltz M, Zilles J, Christianson R, Cooke RAC, Christianson L (2021) Biological nitrate removal with Emerald Ash Borer-killed ash and high-tannin oak woodchips. Front Environ Sci 9(73):648393

Zoski E, Lapen D, Gottschall N, Murrell R, Schuba B (2013) Nitrogen, phosphorus, and bacteria removal in laboratory-scale woodchip bioreactors amended with drinking water treatment residuals. Trans ASABE 56(4):1339-1347

Publisher's note Springer Nature remains neutral with regard to jurisdictional claims in published maps and institutional affiliations. 